\title{
The Study of Modern Russian \\ Literature in China: \\ Correction of Mistakes
}

\author{
Zhao Xue* \\ Siberian Federal University \\ 79 Svobodny, Krasnoyarsk, 660041, Russia
}

Received 25.11.2016, received in revised form 15.12.2016, accepted 11.01.2017

The object of attention in this article is perceptual presupposition, which determines the Chinese Russianists' reception of modern Russian literature and is explained by the specifics of the history of academic reading in China. Under the influence of the policies, like Correction of Mistakes and Emancipating the Mind, Chinese literary scholars comprehended their experience of reception of Russian literature soberly and objectively. They found it necessary to eliminate the gaps, correct the distortions and rehabilitate the writers. The fact of distorted submissions of Russian literature in the twentieth century and the causes of distortion, that Chinese scientists have been aware of, generate an importance of the full view. This presupposition is shown in two ways. One is an effort to maximum grasp of literary material in order to avoid new lacunas, the other is conscious need for not limited by epistemologically ideological analysis, preferring to study the literary phenomenon as a socially determined formally meaningful unity. Another presupposition of research is systematization of representations in modern Russian literature, which shows the definition in four aspects, first, the key social-cultural and proper literary events that defined the movement of literature, second, literary trends, third, aesthetic directions or trends, fourth, the attempt to combine the topical literary phenomenon, and to single out the leading subjects.

Keywords: reception, Russian studies, literary situation, literary process, history of Russian literature.

DOI: $10.17516 / 1997-1370-0015$.

Research area: philology.

\section{Introduction}

The judgment that the conditions of reception determine the direction of the interpretation and evaluation of the text is axiomatic in literary criticism. To understand the way Chinese readers perceive the modern Russian literature, the things they pay attention to, and the things that remain in the so-called "blind spot" (read more about "blind spot" in literary criticism: Govorukhina, 2010) one have to clarify the receptive situation in China. This problem is complex, multifaceted, and relevant to the problem of clarification of the features of intercultural dialogue between modern Russia and China. In this article, the

\footnotetext{
(C) Siberian Federal University. All rights reserved

* Corresponding author E-mail address: zhaoxue1207@gmail.com
} 
authors for the first time distinguish and analyse the presuppositions of perception of a professional Chinese reader, which are predetermined by the specificity of the history of academic reading in China. The novelty of this study lies in the ability to use the Chinese authors' latest monographs on the modern Russian literature.

\section{Statement of the problem}

Since the 1980s, the Chinese literary criticism has experienced the period of critical self-reflection. After the 3rd Plenum of the CPC Central Committee of $11^{\text {th }}$ convocation in 1978, and under the influence of the Correction of Mistakes and Emancipation of Mind courses, Chinese literary scholars began to soberly, objectively, and even rigidly comprehend their experience of reception of Russian literature. Zhou Qichao, a famous Chinese specialist in Russian, admits that looking back on the reception way of Russian literature of the past 100 years, the Chinese literature comes up with the need to eliminate lacunas, correct distortions, and rehabilitate some writers: "We need to bring back the original look of the history of literature" (Zhou Qichao, 2003, p. 14). A distorted perception of Russian literature of the XX century in China was also referred to by Wang Jiezhi in his work "The Reception of Russian Literature and its Interpretation in the Context of Modern Chinese Literature of the XX Century" (Wang Jiezhi, 2010, p. 39). According to Liu Wenfei's "Literary Magic Square: Russian Literature of the XX Century", Russian literature got an incomplete and biased picture. "We often heard the assessment that Russian literature of the XX century is boring and monotonous. The reason for the inadequate perception is that for a long time, there was no complete and objective description of the Russian literature of XX century" (Liu Wenfei, 2004, p. 3).

Chinese scientists distinguish a number of lacunas in the understanding of Russian literature, namely the legacy of the Silver Age, the literature from the middle of the 1960s until the end of the 1970s (the "cooling" of Soviet-Chinese relations), unrealistic literary criticism, prohibited literature, and are aware of reasons for their occurrence.

According to Chinese scientists, one of the reasons is a distorted (raised to the absolute) perception of Russian Marxism and the Soviet literary theory, which were authoritative sources in the formation of the Chinese Marxist literary criticism. However, besides the translation of some works of Marx, Engels, Plekhanov and Lunacharskii, Chinese scholars have also translated and interpreted the works of proletarian activists and representatives of the "vulgar sociology" school (Bogdanov's "About Proletarian Culture"; Fritsche's "Sociology of Art," etc.). These works have strengthened the trend of politicization of literature in China.

Another reason is the post-1949 (the year of New China foundation) perception of Socialist Realism as an aesthetic etalon, the one and only productive principle of creativity and criticism. An absolute status of Socialist Realism in China has led to the uniformity of the creative literary method. Achievements in other areas were ignored. The reader's experience - both professional and non-professional - was entirely focused on the perception of such literature, without any side deviations.

Today, the impact of Socialist Realism on China is regarded as quite deep but destructive. It is believed it has led to the expansion of ultraleft line and the cult of personality and cut off the Chinese literature from the other world literature. For example, Yang Chunshi believes that "Socialist Realism has prevented many kinds of modernist literature such as symbolism, a stream of consciousness literature, fiction, and some more from entering Chinese literature, and causes the criticism of these genres" (Yang Chunshi, 1989, p. 14). Along with the awareness 
of the negative experience of one-sided perception of Socialist Realism, it leads to understanding of incompleteness of ideas of Russian literature of the XX century.

The root of another reason goes back to the period of stagnation of the Soviet-Chinese relations in the mid-1960s - late 1970s, the consequence of which was the prevention of translating Soviet literature into Chinese. At that time, Soviet literature was called as "Sovietrevisionist literature." The works of Ehrenburg, Tvardovskii, Simonov, Shukshin, Sholokhov, and many others were totally denied. This formed another lacuna. Since the beginning of the 1980s, the lacuna has been gradually filled by means of translations and literary-critical/scientific development.

The stage of awareness of "mistakes" in China in the end of the XX century has been replaced by the next stage - the attempts to fill up the lacunas. On this path, Chinese literature has faced quite natural difficulties: the need for a large number of high-quality translations of artistic and theoretical literature; the inadequacy of existed analytical tools for understanding and analysing literary material that goes beyond realism. The hermeneutical problem is complicated by the remoteness of the awareness of the emergence of many works.

Having realized the lack of objectivity in the history of Russian literature, which was created in China, Chinese scientists have attempted to rewrite it. At that time, the search for new historical and literary principles for building a new history of literature was of the utmost importance. Wang Jiezhi was aware of it. In his monograph named "The Reception of Russian Literature and its Modern Interpretation in the Context of Chinese literature of the XX Century," he notes the desire of Chinese Russianists to focus not only on the sociopolitical circumstances that determined the changes in the Russian literature but also on the internal laws of literary evolution and the aesthetic analysis of the text. Wang Jiezhi agrees with Rene Wellek and believes that the history of literature must adhere to the principle of periodization, which would divide it into periods due to the change in the literature itself (Wang Jiezhi, 2010, p. 91). This productive trend has not yet been noticed in "The History of Soviet Literature," released in 1988 under the name of Lei Chengde. In the book, the history of the literature of XX century is shown in the background of the historical class-literary struggle while the selected works are mainly filled with the revolution pathos. This trend has no place for the literature of the Silver Age and it is no accident. In this line, we could also name such books as "Modern Soviet Literature" (1989, edited by Ma Jiajun), "Overview of the Contemporary Soviet literature" (1994, edited by Ye Shuifu). In 1992-1993, the three volumes of "The History of Russian-Soviet Literature" became the official textbook in universities. In this book, Russian classical literature is ended by Chekhov and is followed by the review of Soviet literature while all the legacy of the Silver Age remains a "white spot".

The turning point was in 1998, the year when "The History of Russian Literature of the XX Century" was published under the editorship of $\mathrm{Wu}$ Yuanmai. The author is interested in the internal literature patterns of changing the trends. Some fragments are devoted to modernist literature, postmodernism, and emigre literature. The author divides the book into two parts: the literature of the first half of the XX century (1890-s-1950), and the literature of the second half of the XX century (1950-s-1997). According to $\mathrm{Wu}$ Yuanmai, the USSR began to weaken from the 1950-s, after the death of Stalin, and social upheavals have created various flows in the literature. 
In 2000, "The History of Russian Literature of the XX Century" was released under the editorship of $\mathrm{Li}$ Yuzhen. It contained detailed periodization (the end of XIX century - 1920, 1920-1940, 1941-1954, 1954-1985, 1985-1998) and became an official textbook in many Chinese universities. Using the material of 17 wellknown Russian writers, the author describes the development of Russian literature of the XX century.

The Chinese historians of Russian literature were greatly influenced by the translation of "Russian Literature of the XX Century" by Agenosov (translated by Ling Jianhou, Huang Mei, etc.). Geng Haiying, a professor of Shanghai University, has estimated the book using these words: "This book shows the Russian spirit and image of the literature of the XX century as well as corrects the mistakes of presentation of Russian literature of the XX century not on ideological but rather ideological level." (Geng Haiying, 2003, p. 16).

Guided by the concept of Wellek, Wang Jiezhi wrote "The History of Modern Russian Literature" in 2013. The author refuses to assess the writers and their works on political criteria, the principle of the separation of the history of literature on directions and genres. According to the author, a scholar must adhere to the principle of change of literature itself (Wang Jiezhi, 2013).

Rewriting the history of Russian literature suggests a dramatic process of re-evaluation and re-reading of once being authoritative texts and writers. At the turn of XX-XXI centuries, such re-readings were applied to "Mother" by Gorky, "Quiet Flows the Don" and "Virgin Soil Upturned" by Sholokhov, and other works of Soviet classics (Li Haozhi's monograph "Maksim Gor'kii", Wang Huiling's "Gor'kii's Literary Language," Jiang Tianhui's "Elements of Folk Literature in Gor'kii's Works," Zhang Min's “A sample of the Symbolic Poetry of Modernism: a New Study of "Song of the Stormy Petrel").

In our view, the Chinese scientists' awareness of the fact of distortion of Russian literature of the XX century creates an important receptive presupposition of the completeness of views, which is becoming urgent for the Russian specialists who study the modern Russian literature and understand the danger of repeating the mistakes. In this sense, Chinese scientists' fears are akin to the fears of Russian critics (read more about fears of the modern Russian critics: Govorukhina, 2012). For example, Ankudinov in his "Drugie" article states that a large flow of the latest works does not fit the general literary field and that the critics prefer to write only about famous figures. According to the author, this situation is dangerous and can cause forgetting or lacunas (Ankudinov, 2002).

\section{Discussion. Presupposition № 1}

The presupposition of the completeness of views on modern Russian literature manifests itself in two ways: an effort to cover as much literary material as possible to avoid new lacunas and not to consciously limit oneself to epistemological and ideological analysis, preferring to study the literary phenomenon as a socially determined and formally meaningful unity. Liu Wenfei notes that "with the development of social democracy and economic reform and together with the emergence of a new generation of translators and researchers, the study of Russian literature in China is more and more focused on the artistry and the aesthetic aspects of literature; more and more attention is paid to the scientific and independent literary studies" (Liu Wenfei, 2004). In the reception of modern Russian literature in China, we can define the following features: the focus moves to the study of the text ${ }^{1}$; narratological and stylistic analysis is applied more and more actively; 
works fit not the socio-political but the wider cultural context.

In the mid of 1980s, the Chinese literary criticism actively discussed the idea of an ontological approach to the understanding of literature. It arises as a reaction to the dominance of the mechanistic theory of reflection as well as the need to find the internal regularities of literature development. Fan Yugang considers three vectors of ontological research: formal ontology (being of the text in its constructedness and linguistic incarnation); anthropological ontology (the human being as the centre of literary studies); ontology of life (being in its representation in literature); practical ontology (existence of literature in the dynamic process of communication: the author - the text - the reader) (Fan Yugang, 2009, p. 13).

For a long time, the formula "politicization $=$ artistic value" was the only one in the Chinese literary criticism. In this formula, there is no place for reality. Chinese scientists have long consciously ignored the reflection of reality in literature. The trend of "mistakes' correction" has exposed the need to return the literature to the concept of a real life.

Chinese literature appeared in a difficult epistemological situation. On the one hand, it recognizes the need for vaccination against the "ideological virus" - an ideological reading of a literary text, which prevailed for a long time. On the other hand, it experiences some confusion in the face of diverse analytical practice offered by the western literary theory. In modern China, the theory put forward in 1978 by Mao Zedong, which main ideas were the concepts of practice as the sole criterion for testing truth, is now extrapolated to the area of literary criticism and is still relevant. According to it, the literature should truly and fairly reflect life. "The Check by practice or Life" involves the synthesis of social and aesthetic criticism on the principle of "golden mean". Yan Lianke, a Chinese writer and literary critic, emphasizes this synthesis: "All works of art are necessarily manifested in the aesthetics, but the social reality is usually cruel and ugly. Writers cannot ignore it." (Yan Lianke, 2007, p. 20).

The reflection of life and the life test is the important criteria for the analysis and assessment of modern Russian literature for Chinese scientists. For instance, Ma Weihong, a professor of Shenyang Normal University, states that it is especially important that young Russian poets are accurate in the transfer of mood through the life parts, and that they express "the desire for world harmony and integrity through the focus on the phenomena of life" ("The History and Poetics of Modern Russian Young Poetry" (Ma Weihong, 2012, p. 42). Hou Weihong, a researcher of foreign literature from the Academy of Sciences of China, analyses the oeuvre of Pavlov and describes the word "life" in its various forms, including poverty and concerns two of them as the most common ones (Hou Weihong, 2013, p. 107). The "life test" is also in demand in the study of postmodern texts. Zhang Jianhua, a professor of Beijing Foreign Studies University, in his "Study of Russian Postmodern Prose of the End of the Century on the Materials of Three Stories," admits that the aesthetics of such works as "The Poet and the Muse" by Tolstoy, "The Music of Hell" by Petrushevskaia, and "How We Ate the Rooster" by Popov lies in the fact they reveal the nature of life itself. The authors do not emphasize the plot and do not describe the individual features of characters - they do focus on the state of human life and emotions in reality (Zhang Jianhua, 2001).

\section{Presupposition № 2}

Another research presupposition lies in systematising the concepts of modern Russian literature and it is a consequence of the above- 
stated presupposition of the completeness of views, which excludes (minimizes) "white spots" in literature. In addition, both Russian readers and Chinese specialists in Russian philology were put in a difficult receptive situation with a lot of simultaneously functioning chronologically ("The Returned" and the newest texts), aesthetically, and ideologically literary phenomenon as well as the absence of figures and aesthetic tendencies, "which would have been recognised as central ones by different cultural groups" (Kukulin, Lipovetskii, 2011, p. 635). Such a situation is perceived as a chaotic and is divided into separate phenomena. In the 1990s, Russian criticism virtually rejected the use of the "literary process" concept regarding the latest literary period, which indicates the inability of criticism to see patterns and common trends of the literary movement as well as the continuity with the previous period. It builds a base for occurring of the so-called conceptual "prosthesis": for example, "A Literary Landscape" by Ivanov. Such a receptive confusion is also typical to the Chinese literary critics. For example, Wang Jiezhi in his "The Reception of Russian Literature and its Modern Interpretation in the Context of Chinese Literature of the XX Century" (2010) highlights the most important, in his view, characteristics of the literary situation after the collapse of the USSR (the elimination of the borders between Russian literature and the literature of Russian abroad, the "return" of the forbidden underground literature, the dawn of postmodernism, the presence of the realist movement, the development of religious topics, the strengthening of the position of the mass literature), which make the overall picture of Russian literature "complex and disordered" (Wang Jiezhi, 2010, p. 25). Zhang Jie in his "Russian Literature after the Collapse of the Soviet Union" stated the following: "At present, the general condition of Russian literature is difficult to study, and the reason for that is the increased number of magazines and newspapers complicating the analysis of the literary phenomena" (Zhang Jie, 2005, p. 87).

Studied monographs and articles of Chinese scientists have led to the conclusion that the attempt to present a picture of modern Russian literature is systematically manifested in the determination of: 1) key social, cultural and literary events that defined the movement of literature 2) literary trends; 3) aesthetic directions/trends; 4) an attempt to combine the literary phenomenon thematically and single out the leading "plots."

The attempts to identify and describe trends in the development of modern Russian literature appeared in Chinese Rusistics in the 2000s. The absence of such attempts in the 1990s is explained by scientists as follows: "In 1990, we dealt with the difficulty in synchrony of modern Russian literature. After nearly a decade of knowledge accumulation, we can soberly and clearly see the shape and model of its development" (Zhou Lu, 2013, p. 104).

When defining the main tendencies of development of modern Russian literature, Chinese scientists, for the most part, follow the Russian literary critics.

According to the Chinese scientists, the main trend is pluralism - a simultaneous existence of various literary movements, ideologies, genres, etc. The term "polyphony" has the same meaning. Zhou Qichao in his "The Initial Study of the Main Features of the "New Russian Literature" calls a variety of aesthetic products, created due to the polyphony of artistic manifestations, as the main characteristic of the literature since 1991 (Zhou Qichao, 2002, p. 76). The concept of polyphony is also used by Chen Jianhua, a professor of East China Normal University: "In Russia the economic and social restructuring has profoundly changed the way of life of Russians; these changes have left bright streaks in the Russian literature of 
the 1990s, which are manifested in the form of "polyphony." (Chen Jianhua, 2003, p. 68)

This trend is assessed positively in most studies. Ren Guangxuan, a professor of Peking University, states in his "The Specifics of the Development of Russian Literature after the Collapse of the Soviet Union" that the "pluralism of Russian literature of the 1990s is a "magnificent epilog" of Russian literature of the XX century." He believes that pluralism is the main trend in the development of Russian literature (Ren Guangxuan, 2001, p. 7). Yin Guixiang in her "All Aspects of the Development of Russian Literature in the Period of Disambiguation" almost unites pluralism and equally powerful trend of deideologization in the literature (Yin Guixiang, 2003, p. 100). At the same time, a more critical assessment of the plurality of modern Russian literature is still applied. Yu Yizhong, a famous Chinese specialist in Russian philology, translator, and literary critic, considers the plurality as a sign of zenith in literature and an obstacle to its development: "The fact is that Russian society lacks relatively common social attitudes and the system of literary criticism, which leads to the fact that the creativity of writers can't be timely and correctly regulated." He calls this condition as "unbearable lightness of writers' creativity" (Yu Yizhong, 2001).

Another trend regarded as an important one by Chinese scientists is the marginalization of modern Russian literature, or the crisis of literary centrism. Ren Guangxuan in "The Specifics of the Development of Russian Literature after the Collapse of the USSR" states that "since the 90s of the XX century, people have lost interest in literature, and, as a result, it has lost its leading status" (Ren Guangxuan, 2001, p. 7). According to Hou Weihong, "the literature moved away from the politics, and it is not in the centre of the social need, and no longer synonymous with Russian culture" ("The study of modern Russian prose" - (Hou Weihong, 2013, p. 18)). Zhang Jie in "Russian Literature after the Collapse of the USSR" also believes that "the status of literature in the social life is sharply reduced; it has moved to the periphery from the position closer to the centre" (Zhang Jie, 2005, p. 83).

The causes of the crisis of literary centrism, which is observed by the Chinese specialists in Russian philology, are similar to the Russian interpretation of this phenomenon. According to Wang Xian's dissertation named "Pelevin in China and the influence of Russian post-1990s literature on China," "the cause of the crisis of literary centrism is the existence of a context of post-colonialism." The author believes that "After the collapse of the Soviet Union, postcolonialism greatly affects the different areas, (including economic, political, scientific and technical, cultural, etc.) as well as changes the structure of artistic culture. Such an influence to some extent weakens the charm of Russian literature "(Wang Xian, 2009, p. 16).

Chinese scientists are more optimistic than the Russian counterparts regarding the estimation of the crisis of literary centrism. Zhang Jianhua in his "Integration of Russian Literature into the World Literature," says that "in the context of globalization, and modern Russian literature has not lost its national characteristics the tradition of caring about reality, the history, and the awareness of one's vocation as a natural feature of Russian literature are still the main landmarks of modern Russian writers. Although literature no more regulates the country's events, writers still protect the nobility of the human spirit and spiritual beauty. The literature still plays an important role in the spiritual life of man. The literature has its own regularity development, and in the case of occurring of the dominant tradition, it will show its power of self-discipline" (Zhang Jianhua, 2014, p. 39). 
To define the key directions/trends in modern Russian literature is also a form of material systematization. This is the basic principle for the whole picture of modern Russian literature in the Sun Chao's monograph "Study of Russian Novels and Short Stories of 80 -s-90-s of XX Century, Hou Weihong's “The Study of Modern Russian Prose." The latter analyses the main literary trends after the collapse of the Soviet Union, highlighting realism, postmodernism, and post realism as the main ones. According to Hou Weihong, the modern Russian realism exists in several variants. The first is a new critical realism that continues the traditions of Russian literature of the XIX century, but more radically criticizing the modern society. Also, it expresses emotions tougher and straighter. According to the scientist, "many of the works demonstrate a frank publicism and polemics. For example, "Two Girlfriends Lost in Bread" by Astaf'ev, "Bermuda Triangle" by Bondarev, "By-Place" by Vasil'ev, "Daughter of Ivan, Mother of Ivan " by Rasputin and "The Tale of the Last Days" by Pavlov <... these works do not just describe and disclose the negative social factors before the collapse of the USSR, but also vigorously denounce a number of problems after the collapse as well as show great concern about the future of the country and the nation "(Hou Weihong, 2013, p. 102). The second type of realism is a new realism. Regarding new realism, scientists agree with Remizov's ideas that the new realism absolutely truthfully describes the reality, almost entirely abandons fiction, falsehood, and, as a result, presents a cruel and dark world. That's why Hou Weihong calls the new realism as "dash line." This metaphor means accurate writing, without decorations and beautiful phrases. The author refers Shargunov's and Senchin's creativity to the new realism. The third type of realism is mentioned in the Hou's "Inheriting Traditions and Plural Development - the Modern Russian Realistic Prose" article.
According to the author, the magic realism is a version of realism, which has an obvious mystical tinge. The mystery of the magic realism takes two forms: 1) a description of mystical phenomena and events in real life; 2) revealing the secrets of the inner spiritual world. She considers "Incident of Kukotskii" by Ulitskaia, "The Sunken Ark," and "The Dome" by Varlamov as a mystical realism (Hou Weihong, 2007, p. 107). Sun Chao calls this prose "a prose of metaphors" and refers to it the works of Makanin, Petrushevskaia, Kim, Kurchatkin, and others.

Various modifications of realism in modern Russian literature are special objects of attention of Chinese scientists. They consider saving/ development of a realistic line as a productive way for Russian literature. According to Zhang Jianhua, "the support of realistic literature is an important choice of Russian literature in satiation of the transformation of postmodern culture", a chance to keep up the status in the situation of globalization (Zhang Jianhua, 2012,

p. 256). Here the important thing is the problem of self-identifying, which is relevant to China, and through the prism of which the Chinese literature estimates Russian literary phenomenon. The saving of the traditions of realism is conceived as the preservation of the national literary specificity.

Chen Jianhua in his paper "The Transformation of Russian Realistic Literature at the Turn of the Centuries" reflects the future of realistic literature by predicting a bright future for it: "Russian realistic literature has a bright future in the XXI century. Under the challenges of modernism and postmodernism, realistic literature has overcome the crisis and completed the transition from a closed, mechanical and uniform artistic model to a flexible, open and changing art form "(Chen Jianhua, 2008).

According to Hou Weihong's interpretation, post realism implies the manifestation of 
existential worldview within the frames of realist paradigm, as well as the active use of the elements of modernism and postmodernism. Hou Weihong believes that "post realistic prose is not completely absorbed by existentialism, so we are able to see the care of reality, criticism of social injustice, and the desire to protect the dignity and freedom of the person through the visible/invisible indifference." (Hou Weihong, 2013, p. 77).

Zhang Jianhua, a professor of Beijing Foreign Studies University, interprets post realism as a manifestation of a more general trend of synthetism (monograph "Russian Literature of the XX century: ideological trends and directions") (Zhang Jianhua, 2012, p. 303). He uses the terms "Prose synthetism," making an accent on the issue that the number of facts cannot be reduced to realism or postmodernism or limited by any other directions. Zhang Jianhua names Makanin as a representative of this literature since the pose of the latter includes elements of surrealism, postmodernism, and realism (Ibid., p. 306).

Another important area, by which Chinese scientists create the contemporary literary field, is postmodernism. The view of its development stages coincides with the Russian: the emergence in the 1960 s, the heyday after the Soviet collapse, and the fading without disappearing at the turn of XX-XXI centuries (despite the fact it still has a significant impact on modern people).

There are different opinions of Chinese scientists regarding the question of crisis/death of postmodernism in Russia. For example, Li Xinmei, a Chinese specialist in Russian, in his "Reality and Illusion - an Artistic Picture of Postmodern Pelevin's Prose" suggests an extreme version of the death of postmodern literature. She believes that in the XXI century, the postmodern literature reveals a new trend of development: the absorption of realism, the overcoming of the irrepressible game/ grotesque/deconstruction, and the return of morality, traditions, religious and love themes (Li Xinmei, 2012, p. 64). Wang Zonghu, a professor of The Beijing Normal University, believes that "the development of Russian postmodern literature reveals the tendency to extinction, but that does not mean the death of postmodernism. In accordance with the idea of Lotman, having survived the cultural boom, the literary model entered a period of stable development. The interconnection of postmodernism with other areas is followed by the emergence of a compromise aesthetic value" (Wang Zonghu, 2012, p. 279).

A thematic/plot principle of systematization of modern Russian literature is quite common in China as well.

Chen Jianhua, a professor of East China Normal University, defines "the literature of introspection" as a separate event. In his "Russian Literature in the Period of Disambiguation" (2003), he calls the principal plots of the Russian literature of the late XX century. The author defines the direction of self-examination ("understanding the past history") as a primary one, stating that it differs from the analog of the 1980s by the religious and philosophical subtext (Chen Jianhua, 2003, p. 69). We can find such a plot in "The Plot of Averaging" by Makanin, "Cursed and Killed" by Astaf'ev, "The General and his Army" by Vladimov, "The Temptation" by Bondarev, "Gogol's Head" by Korolev, and others. Zhou Qichao in his "Primary Research of the Basic Features of the New Russian Literature" sees the same tendency of deepening and broadening the subtext (from socio-historical to historical and cultural) in the literature of introspection. He defines this trend as a general tendency for the literature: "A macroscopic interpretation of Russian national and cultural characters will gradually become the general trend of literature, both liberal and traditionalist" (Zhou Qichao, 2002, p. 79). 
All Chinese specialists in Russian philology determine the theme of war as the most important in the literary of modern Russia. They admit the dynamics in the development of modern military prose - right in the same way as Russian colleagues find novelty in dealing with the theme in the 1990s compared with the previous period: the expansion of the illustrated material (Great Patriotic War, Afghanistan War, Chechen War) and the strengthening of the strategy of "the truth of the fact." Zhao Jianchang in his "The Continuity and Development after the Collapse: the Description of Modern Military Literature" detects a change in the type of narration in the process of art history reconstruction "Earlier, writers tended to show the panoramic image while the modern military prose emphasizes the historical events that accurately display the historical reality" (Zhao Jianchang, 2008, p. 134). Hou Weihong admitted that such young writers as Gutsko and Pavlov deconstructed the "military justice - injustice" opposition, making accents on all personal (personal senses, personal experience of war) and introduced a new morally/spiritually weak character (Hou Weihong, 2013, p. 37).

Within the plot of "loss/search for the foundations of being," Chinese scientists are primarily studying the "village prose". In the monograph "The study of Modern Russian Prose", Hou Weihong emphasizes that this prose of a new period captures the decaying .of the village after the disambiguation as well as the collapse of moral and spiritual foundations and traditions (Ibid., p. 31).

The plot of lose/search for the foundations is discovered by Rusists in women's literature, with its emphasis on the theme of family and love. Chen Fang, a professor of Renmin University of China, in his "The Study of the Modern Russian Women's Prose", calls hopeless and lost love as the main situation in the women's prose (Chen Fang, 2007, p. 63). According to Yu Zhengrong, it is the women's prose that accurately captures the destruction of a family and its revival (Yu Zhengrong).

Within the "urban plot," Chinese scientists identify the image of the modern intellectuals in a situation of social demolition. According to Jiang Lei, "The intellectuals in modern Russian literature evolve from an escape from reality to the thirst for reality" (Jiang Lei, 2015, p. 66). According to Chen Jianhua, "Generation P" by Pelevin, "Bermuda Triangle" by Bondarev, "The New Profession" by Rasputin, "Liberty" by Butov, "Thinking of Russian and American" by Iskander, "Underground, or a Hero of our Time" and "Laz" by Makanin, and "Country House" by Varlamov are the works that truthfully disclose a new image of the Russian intelligentsia (Chen Jianhua, 2003, p. 72).

\section{Conclusion}

So, the receptive situation in contemporary China is that the Russianists, relevant to an academic environment, put forward the idea of completeness and systematic view of modern Russian literature. The announced policy of "mistake correction" and "emancipation of mind" has led to the revision of the existing ideas about the history of Russian literature of the XX century, and existing analytical literary tools. The Chinese scientists' awareness of the fact of the distorted picture of Russian literature of the XX century and the distortion causes gave birth to the awareness of a risk to repeat the mistakes. The line of the completeness view is found in the desire of full coverage of literary material to avoid new lacunas, the conscious need of not limiting oneself to either epistemological or ideological analysis, the study of literary phenomena as socially determined and formally meaningful unity. The presupposition of a systemic view 
is manifested in the attempts to single out the key sociocultural and literary events, literary trends, and aesthetic directions in the literature of the turn of XX-XXI centuries as well as the attempt to combine the literary phenomena thematically and single out the leading plots.
The mentioned lines, directions and presuppositions make it possible to assume that in the 2000 s, China is experiencing a new stage of perception of Russian literature. This stage is free of copying and ideological reading and requires careful scientific understanding.

\footnotetext{
For example: monograph "Postmodern Narrative Model in Sorokin's Works" (Wen Yuxia, 2014), article "The New Thinking and Narrative in New Political Prose - the 1990s' short stories of Aleksander Solzhenitsyn" (Zhang Jianhua, 2009), article "The Fragmentation of Narrative in the Novel 'Buddha's Little Finger"' (Chen Lu, Duanzhaoxia and Xu Suihui, 2010), article "Narrative Strategy as a Game in Russian Postmodern Prose - by the Example 'Buddha's Little Finger" (Zheng Yongwang, 2010), article "Ugly' Narrative Model in Sorokin's prose" (Wen Yuxia, 2011), article "Analysis of the Mechanism of Narrative Discourse in "Matisse"” (Chen Aixiang, 2008), article "The Narrative Strategy of Makanin's Metafiction" (Wang Lidan, 2005), monograph "The Themes and Poetics of Ulitskaia's Works in the Context of Modern Russian Literature" (Sun Chao, 2012), article "The Poetics of Russian Postmodern Literature" (Li Xinmei, 2008), Master's thesis "Analysis of the Poetics in Tolstaia's Prose" (Tian Lu, 2009), Master's thesis “The Themes and Poetics in Petrushevskaia's 1990s' Prose" (Liu Yang, 2013), article "Stylistic Devices in the Tokareva's Prose " (Dai Shan, 2009), article "The Art Style of the Makanin's Prose" (Hou Weihong, 2001), article "The Art Style in Russian Postrealistic Literature" (Wang Min,2015), and others.
}

\section{References}

Ankudinov, K. (2002). Drugie [The Others], In Okt'iabr' [October], 11.

Govorukhina, Iu. (2010) Literaturno-kriticheskii diskurs kak otkrytaia sistema [Literary-Critical Discourse as an Open System], In Vestnik Tomskogo gosudarstvennogo universiteta. Filologia [Bulletin of the Tomsk State University. Philology], 2, 58 - 67.

Govorukhina, Iu. (2012). Tolstii zhurnal na rubezhe 20-21 vekov: ideinaia diffuzia i gnoseologicheskii sterzhen' [Large-Volume Magazine at the Boundary of the XX-XXI Centuries: Ideological Diffusion and Gnoseological Core], In Zhurnal Sibirskogo federal'nogo universiteta [Journal of Siberian Federal Uuniversity], 5, 347-357.

Kukulin, I., Lipovetskii, M. (2011). Postsovetskaia kritika i novyi status literatury v Rossii. Istoria russkoi literaturnoi kritiki: sovetskaia i postsovetskaia epokhi [Post-Soviet Criticism and a New Status of Literature in Russia. The History of the Russian Literary Criticism: Soviet and Post-Soviet Epochs]. Moscow, New Literary Review.

Wang, Xian (2009). Pelevin in China and The Influence of Russian Post-1990s Literature on China: Master's thesis. Gui Zhou.

Wang, Jiezhi (2013). The History of Modern Russian Literature. Beijing: China Social Sciences Publishing House.

Wang, Jiezhi (2010). The Reception of Russian Literature and its Interpretation in the Context of Modern Chinese literature of the XX Century. Beijing: Beijing Normal University Publishing House.

Geng, Haiying (2003). The Rewriting of the History of Russian Literature, In Journal of Guangzhou University, 8.

Ren, Guangxuan (2001). The Specifics of the Development of Russian Literature after the Collapse of the Soviet Union, In New Perspectives on World Literature, 6.

Yin, Guixiang (2003). All Aspects of the Development of Russian Literature in the Period of Disambiguation, In Journal of Fudan University, 2.

Li, Xinmei (2012). Reality and Illusion-Artistic Picture of Postmodern Pelevin's prose. Shanghai: Fudan University Publishing House. 
Liu, Wenfei (2004). Literary Magic Square: Russian Literature of the XX Century. Beijing: China Social Sciences Publishing House.

Liu, Wenfei (2004). Perevod i izuchenie russkoi literatury v Kitae [Translation and Study of Russian Literature in China], In Novoe literaturnoe obozrenie [New Literary Review], 69.

Ma, Weihong (2012). The History and Poetics of Modern Russian Young Poetry, In Journal of Shenyang Normal University, 5.

Fan, Yugang (2009). The Reflection of Ontological Literary. Currents and its Proper Way of Development, In Guizhou Social Sciences, 10.

Hou, Weihong (2013). The Study of Modern Russian Prose. Beijing: China Social Sciences Publishing House.

Hou, Weihong (2007). Inheriting Traditions and Plural Development - the Modern Russian Realistic Prose, In Contemporary Foreign Literature, 3.

Jiang, Lei (2015). The Study of Images of Modern Intellectuals in the New Russian Literature, In Contemporary Foreign Literature, 4.

Zhang, Jie (2005). Russian Literature after the Collapse of the USSR, In Russian Studies, 3.

Zhang, Jianhua, Wang Zonghu, Wu Zelin (2012). Russian Literature of the XX Century: Ideological Trends and Directions. Beijing, Foreign Language Teaching and Research Press.

Zhang, Jianhua (2014). Integration of Russian Literature into the World Literature, In Foreign Literature, 2.

Zhang, Jianhua (2001). The Study of Russian Postmodern Prose of the End of the Century on the Materials of Three Stories, In Foreign Literature, 1.

Zhao, Jianchang (2008). The Continuity and Development after the Collapse: the Description of Modern Military Literature. In Contemporary Foreign Literature, 2.

Zhou, Lu (2013). The Influence Booker Prize on Russian Literature for 20 years. In Journal of Tongji University, 2.

Zhou, Qichao (2002). The Initial Study of the Main Features of the «New Russian Literature». In Journal of Huanghe $S \& T$ University, 1.

Zhou, Qichao (2003). Silver Age of Russian Literature. Beijing, The Peking University Publishing House.

Chen, Fang (2007). The Study of the Modern Russian Women's Prose. Beijing, China Renmin University Press.

Chen, Jianhua (2003). Russian Literature in the Period of Disambiguation, In Journal of East China Normal University, 3.

Chen, Jianhua (2008). Transformation of Russian Realistic Literature at the Turn of the Centuries, In Journal of Tongji University, 5.

$\mathrm{Yu}$, Yizhong (2001). The Development of Russian Literature in the 1990s, In Contemporary Foreign Literature, 4.

Yang, Chunshi (1989). Criticism of Socialist Realism, In Literature \& Art Criticism, 2.

Yan, Lianke (2007). The Current Relationship between Literature and Reality, In Yangtze Criticism, 1. 


\section{Изучение современной}

\section{русской литературы в Китае: \\ «работа над ошибками»}

Чжао Сюе

Сибирский федеральный университет Россия, 660041, Красноярск, пр. Свободныий, 79

В статье вычленяются рецептивные установки, которые определяют восприятие китайскими русистами современной русской литературы: установки на полноту и системность взгляда, ставшие актуальными в связи с объявленным курсом на «исправление ошибок» и «раскрепощение сознания» в Китае. Осознание китайскими учеными факта искаженного представления о русской литературе ХХ века и причин искажения породило понимание опасности повторения ошибок. Установка на полноту взгляда обнаруживается в стремлении максимально охватить литературный материал и в осознанной необходимости не ограничивать себя гносеологически идеологическим анализом. Установка на системность взгляда проявляется в попытках вычленить в литературной ситуации рубежа XX-XXI веков ключевые социокультурные и собственно литературные события, литературные тенденции, эстетические направления/течения, в попытке объединить литературные явления проблемно-тематически, вычленить ведущие «сюжеты»».

Ключевые слова: рецепџия, китайская русистика, литературная ситуация, литературный прочесс, история русской литературы.

Научная специальность: 10.00.00- филологические науки. 